\title{
Outomatisasie: konsepte en verskillende beskouings
}

\section{J. Gouws}

Departement Elektriese en Elektroniese Ingenieurswese, Randse Afrikaanse Universiteit, Posbus 524, Aucklandpark, 2006

E-posadres: jg@ingl.rau.ac.za

Ontrang 17. September 1998; anvaar 9 Desember 1998

\section{UTTTRLKSILL}

Verskillende mense het verskillende sieninge oor outomatisasie - gewoonlik iewers in 'n spektrum tussen wonderwerk en euwel. Sommiges beskon outomatisasie as ' $n$ wonderkun vir arbeids- of bestumrsprobleme, of as iets wat moeilike of ondefinieerbare take kan uitvoer. Andere meen dat dit iets is wat werkgeleenthede wegneem, of wat ten dunrste onderhou moet word. Aangesien outomatisasie toenement deel word van ons samelewing, is dit belangrik om die konsep behoorlik te verstaan. Hierdie artikel is daarop gemik om 'n meer gehalanseerde beskouing van outomatisasie te vestig. Die klem val op basiese konsepte en dryfiere, verskillende vlakke ran outomatisasie. potensiële voordele, en op enkele belangrike redes vir witeenlopende beskouings oor outomatisasie

\section{ABSTRAC'T}

\section{Automation: concepts and different views}

Differem people have different views on automation - normally somewhere on a spectrm benween miracle and evil. Some people consider antomation as a wonder cure for labour or management problems, or something which can per form difficult or undefined rasks. Others see it as something which reduces job opportunities, or which has to be maintained at high cost. Since antomation is increasingly becoming part of our society, it is important to fully understand the concept. This paper is aimed at establishing a more balanced view of automation. The emphasis is on basic concepts and driving forces, different levels of automation. potential adrantages, and on some important reasons for different views on antomation

\section{INLEIDING}

\subsection{Agtergrond}

Die begrip outomatisasie beteken vir verskillende mense verskillende dinge en selfs vakspesialiste verskil soms van mekaar hieroor. Sommiges sien dit as 'n wonderwerk wat kan help om moeilike take te verrig, of on arbeids- of bestuursprobleme te oorbrug. Andere sien dit as 'n euwel wat werksgeleenthede bedreig ell nog andere as slegs ' $n$ versameling masjiene wat deur 'wetenskaplikes' aanmekaargesit is. Aangesien outomatisasie toenemend deel word van ons samelewing, is dit belangrik dat hierdie konsep beter verstaan moet word. Om dit reg te kry, is ' $n$ gebalanseerde beskouing van beide die voor- en die nadele van outomatisasie nodig; en is dit ook noodsaaklik dat tegniese sowel as sosio-ekonomiese aspekte in ag geneem word. Hierdie artikel is 'n stap in dié rigting, deur enkele belangrike konsepte rondom outomatisasie kortliks te verduidelik, deur te kyk na 'n outomatisasie-hiërargie en dit met voorbeelde te illustreer, deur enkele potensiële voordele van outomatisasie uit te lig, en deur die belangrikste redes waarom daar uiteenlopende sienings oor die onderwerp bestaan, waarneembaar te maak.

\subsection{Basiese konsepte}

Woordeboeke definieer outomatisasie min of meer as iets wat self werk, sonder menslike inmenging. Hierdie definisie is egter vaag, en juis daarom word die term heel dikwels verkeerd gebruik. Veral bemarkingsbrosjures (en deesdae ook die Internet) word gebruik om op 'n populêre, soms sensasionele wyse, inligting oor outomatisasie van byna enigiets te verkondig, vanaf aankope-outomatisasie, volledige outomatisasie van fabrieke - toegangsbeheer, voorraadbeheer, ens. -- tot by outomatiese zebra-volging in wildtuine (outomatiese bio-telemetriestelsels vir dierevolging'). As daar egter krities na baie van hierdie toepassings gekyk word, is dit duidelik dat die woord outomatisasie dikwels hoofsaaklik gebruik word om die leser se aandag te trek. So word vurkhysers soms onder die vaandel van outomatiese materiaalhantering geadverteer; en gewone elektroniese komponente of persoonlike rekenaars onder die vaandel van gevorderde outomatiese toerusting. Die verband tussen die geadverteerde toerusting en werklike outomatisasie is egter dikwels maar baie skraps.

Dit is nie net bemarkers wat aan misbruik van die woord outomatisasie skuldig is nie, maar selfs sommige tegniesopgeleide persone val in dié slaggat. 'n A lgemene fout wat gemaak word, is om meganisasie en outomatisasie as sinonieme te beskou. Meganisasie is die aanvulling (of vervanging) van spierkrag d.m.v. masjiene. Alhoewel meganisasie die fisiese las van werkers kan verlig, word werkers steeds benodig as operateurs wat die gebruiksaanwysings van die masjiene moet verstaan en uitvoer. Outomatisasie, daarenteen, is die aanvulling (of vervanging) van spierkrag, breinkrag en sensoriese vermoëns d.m.v. masjiene (hoofsaaklik aanpasbare rekenaargebaseerde masjiene). Met outomatisasie kan sekere take totaal outonoom deur 'n masjien uitgevoer word, sonder enige inmenging of toesig deur 'n operateur, terwyl hierdie vermoë nie by gemeganiseerde stelsels bestaan nie.

'n Gewone vurkhyser is beslis slegs 'n spiervervangingshulpmiddel. Eers wanneer dit sonder 'n operateur kan rondbeweeg, sonder om in obstruksies langs die pad vas te ry, en self kan besluit watter voorwerpe waar gehaal moet word en waarheen dit dan geneem moet word, kan vurkhysers en outomatisasie in dieselfde sin gebruik word. Netso moet in persoonlike rekenaar eers behoorlik geprogrammeer word en met aktueerders verbind word voordat dit enigsins soos outomatisasie kan begin lyk.

Outonome waarneming en besluitneming deur ' $n$ masjien is die hoekstene waarop outomatisasie gebou word. By meganisasie word albei hierdie take deur 'n operateur gedoen. Dit is baie belangrik om daarop te let dat besluitneming deur 'n masjien hoofsaaklik op 'n geprogrammeerde wyse plaasvind - m.a.w soos voorgeskryf deur 'n menslike programmeerder; en met elke keer dieselfde resultaat vir 'n gegewe stel insette (tensy willekeurigheid in die program ingebou word). Dit verskil van menslike besluitneming, wat nie net van insette afhang nie, maar 
ook van onvoorspelbare emosies.

Dikwels word daar verkeerdelik gedink dat take wat moeilik definieerbaar en moeilik uitvoerbaar is, bloot geoutomatiseer moet word ten einde van die moeilikhede ontslae te raak. Om dit reg te kry, kom die beeld van 'n robot, in die vorm van 'n meganiese mens, vol wonderlike elektronika, met bomenslike krag, maar netnet nie genoeg verstand om teë te praat nie, dan in die gedagtes op. ${ }^{2}$ Hierdie benadering is die basis van die wonderwerkbeskouing van outomatisasie. ${ }^{3}$ Die werklikheid is egter dat die doelwitte en die basiese werking van enige proses eers behoorlik verstaan moet word voordat dit geoutomatiseer kan word. Moderne outomatisasie is bloot die rekenaarmatige implementering van prosesse wat andersins deur 'n menslike operateur uitgevoer sou moes word. As daar nie vooraf verstaan word wat die operateur sou moes doen nie, kan so 'n taak nie aan 'n rekenaar (of ' $n$ ander masjien) oorgedra word vir uitvoering nie. Die blote eienaarskap van 'n rekenaar of van 'n robot is nie ' $n$ waarborg dat probleme opgelos kan word nie. Dit moet eers behoorlik geprogrammeer en dan deurlopend onderhou word, voordat dit kan help om take te verrig. Outomatisasie vat nie die mens se verantwoordelikheid weg nie, maar dit herskeduleer, hergroepeer en herdefinieer bloot die mens se funksies. Dit neem sekere verantwoordelikhede oor, maar dit bring ander nuwe verantwoordelikhede in die plek daarvan. So kan outomatisasie die nodigheid vir 'n operateur by ' $n$ bepaalde proses wegneem, terwyl dit die nodigheid skep vir ingenieurs, tegnici en ambagslui om 'n masjien te maak en te onderhou wat die operateur se takk kan oorneem. Een stel menslike funksies word dus slegs deur 'n ander stel vervang.

\subsection{Dryfvere vir outomatisasie}

In die loop van ekonomiese ontwikkeling in enige land vind 'n natuurlike migrasie van arbeid plaas, al hoër op in die arbeidshiërargie. ${ }^{4}$ Jare gelede het hierdie migrasie vinniger gebeur as wat tegnologiese ontwikkelings plaasgevind het. Meganisasie en outomatisasie het dus hoofsaaklik leemtes gevul wat reeds in die primêre sektore se arbeidsmark ontstaan het as gevolg van die natuurlike migrasie van arbeid - sogenaamde behoefte-gedrewe meganisasie en outomatisasie. Mettertyd is 'n stadium egter bereik waar die tempo van arbeidsmigrasie weg vanaf die basiese sektore van die ekonomie begin afplat het, maar waar die tempo van tegnologiese ontwikkelings terselfdertyd drasties toegeneem het. Dit het 'n situasie laat ontstaan waar masjiene vinniger ontwikkel word as wat daar leemtes in die arbeidsmark ontstaan; en dit gee aanleiding tot sogenaamde tegnologie-gedrewe of vermoëgedrewe meganisasie en outomatisasie.

Tegnologie-gedrewenheid het tot gevolg dat werkers wat nie opwaarts wil of kan beweeg in die arbeidshiërargie nie, se werkgeleenthede deur outomatisasie bedreig kan word. Die dryfveer vir outomatisasie het dus grootliks verander vanaf 'n behoefte-gedrewenheid (leemtes waarvoor oplossings gesoek word), na 'n tegnologie-gedrewenheid (oplossings waarvoor probleme gesoek word). Om die gevolge wat hierdie verskynsel op werkers het reg te hanteer, verg noue samewerking tussen ingenieurs, sosioloë, ekonome en bestuurders - en dit is samewerking wat nie altyd maklik gebeur nie, weens kompartementalisering van hierdie professies.

Daar kan nou tereg gevra word waarom tegnologie dan ontwikkel word waarvoor daar nog nie behoeftes bestaan nie. Die antwoord is: grotendeels om die mens se nuuskierigheid te bevredig. Dit is die kern van hasiese navorsing — een van die hoekstene waarop 'n universiteit gebou is.

\section{VERSKILLENDE VLAKKE VAN OUTOMATISASIE}

\subsection{Outomatisasie as proses}

Outomatisasie kan soos in figuur l blokdiagrammaties voorgestel word. Met die blokdiagram word nie probeer om outomatisasie en terugvoerbeheer as sinonieme voor te stel nie, maar slegs om outomatisasie aan die hand van die basiese beginsels van terugvoerbeheer te verduidelik. Die elemente van figuur I kan soos volg beskryf word:

- taakdefinisie (definisie van dit wat gedoen moet word en hoe goed dit gedoen moet word: definisie van die verlangde uitset van die geoutomatiseerde proses);

- waarneming (bepaling / meting en interpretasie van dít wat wel gedoen word: omskakeling van werklike nitset na gemere uitset);

- vergelyking (bepaling van afwykings tussen die verlangde en die gemete uitset: bepaling van die foutsein);

- besluitneming (keuse van aksies gerig op uitskakeling van die foutsein, deur die foutsein on te skakel na 'n geskikte beheersein, waarmee taakuitvoering beheer kan word); en

- taakuitvoering (uitvoering van die taakdefinisie, met inagname van resultate van waarneming, vergelyking en besluitneming).

\subsection{Outomatisasie-hiërargie}

Meganisasie behels hoofsaaklik die gebruik van masjienhulp vir taakuitvoering, terwyl volledige outomatisasie behels dat elk van die vyf take soos in figuur 1 getoon, met masjienhulp gedoen word, sonder menslike inmenging. Outomatisasie kan egter in verskillende grade gedoen word en in 'n outomatisasie-hiërargie voorgestel word. Een so 'n algemeen gebruikte voorstelling word in figuur 2 getoon, terwyl tabel I 'n ander voorstelling daarvan is. (Verskillende ander kombinasies as dié wat in tabel I getoon word, is ook nog moontlik; en die benamings is geensins gestandaardiseerde terme nie.)

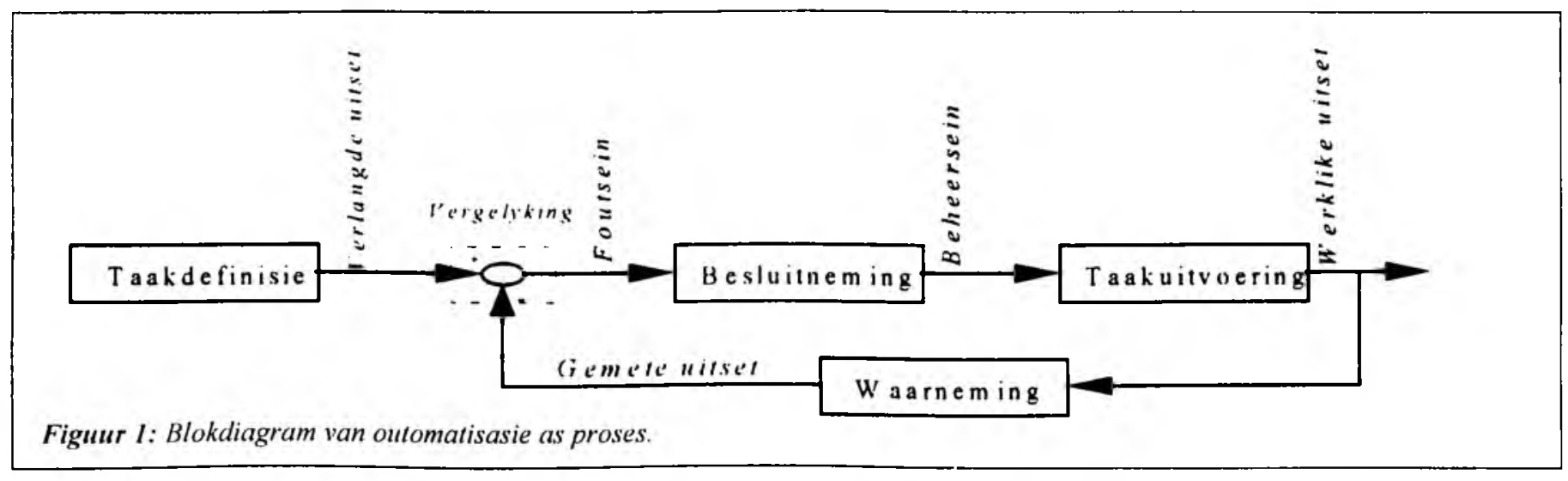




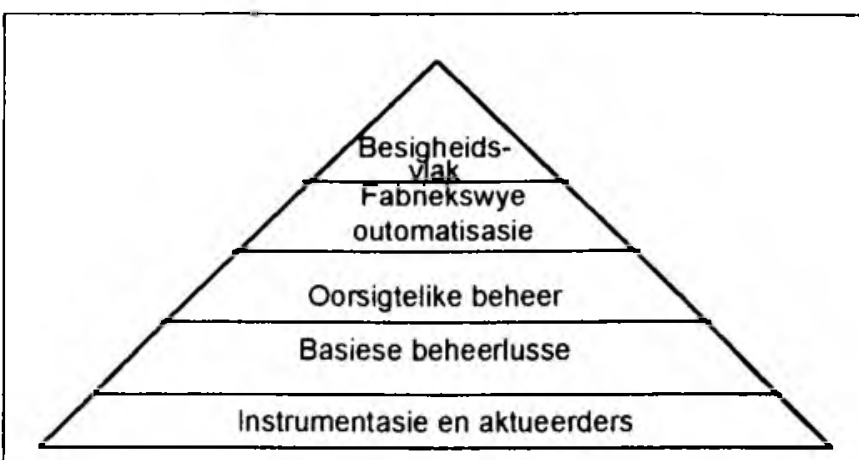

Figuur 2: 'n Algemeen gebruikte voorstelling van 'n outomatisasie-hierargie.

Tabel 1 Alternatiewe voorbeeld van 'n outomatisasiehiërargie

\begin{tabular}{ll}
\hline Benaming & \multicolumn{1}{c}{ Beskrywing } \\
\hline Meethulpstelsel & - Taakdefinisie word deur 'n operateur gedoen \\
& - Outomatiese warneming (meting) van werklike \\
& uitset (d.m.v. outomatiese meettoerusting) en terug- \\
& voering van gemete uitset na die operateur \\
& Operateur vergelyk gemete en verlangde uitsette, \\
& neen besluite, en doen taakuitvoering (gewoonlik \\
& met masjienhulp) \\
Meet- en & Taakdefinisie word deur 'n operateur gedoen \\
berekenings- & Outomatiese waarneming van werklike uitset \\
bulpstelsel & Outomatiese vergelyking van gemete en verlangde \\
& uitsette, en berekening van foutsein \\
& Operateur reageer op foutsein en doen taakuit- \\
& voering op grond daarvan (met masjienlutp)
\end{tabular}

Belieerhulpstelsel - Taakdefinisie word deur 'n operateur gedoen

- Outomatiese warneming, vergelyking en besluitneming, met terugvoering aan operateur, wat besluit moet uitvoer

Outomatiese beheer - Taakdefinisie word deur 'n operateur gedoen

- Outomatiese waarneming, vergelyking, besluitncming en taakuitvoering

Volledige outomatisasic

- Outonome taakdefinisie, waarneming, vergelyking, besluitneming en taakuitvoering

- Geen direkte operateurbetrokkenheid

Die eerste vier inskrywings in tabel 1 maak telkens gebruik van 'n taakdefinisie wat deur 'n operateur gedoen word - wat dit onderskei van volledige outomatisasie, waar taakdefinisie ook deur 'n masjien (rekenaar) gedoen word. (Let egter daarop dat alhoewel die taakdefinisie in die laaste geval deur 'n masjien gedoen word, moes 'n mens eers vooraf die oorhoofse taakdefinisie doen en moes hierdie opdrag dan in 'n rekenaar geprogrammeer word. Eers daarna kan die masjien hierdie opdrag herhaaldelik uitvoer.)

In die volgende afdeling word voorbeelde gegee van hierdie verskillende vlakke van geoutomatiseerde prosesse, ten einde die inskrywings in tabel 1 van nader te illustreer.

\subsection{Voorbeelde van verskillende vlakke van outomatisasie}

Die voorbeelde wat hier gegee word, bevat nie volledige besonderhede nie; en alhoewel die take vir die doel van die voorbeelde uitmekaar getrek is, vind dit dikwels interaktief en geïntegreerd plaas. (By elke voorbeeld word die name van dié prosesse wat outomaties gedoen word, kursief gedruk.) lndien die voorbeelde in hierdie afdeling eng gelees word, mag die idee dalk ontstaan dat elke vlak van outomatisasie toenemend daarop gemik is om menslike take minder te mak. Dit is egter beslis nie die geval nie, want soos in afdeling 1.2 hierbo reeds gesê is, word een stel menslike take deur 'n masjien oorgeneem, maar die ontwerp, vervaardiging en onderhoud van die masjien bring 'n nuwe stel menslike take mee. Agter elke suksesvolle outomaat staan steeds 'n span hardwerkende mense.

\section{Tabel 2 Voorbeeld van 'n meethulpstelsel}

\begin{tabular}{ll}
\hline Voorbeeld & Omgewingswatrnemingstelsel op groot voertuie \\
\hline Opmerkings & Swatvoertuie is soms in botsings betrokke wanneer daar \\
& agteruitgery word. omdat die besturder moeilik direk agter \\
& die voertuig kan sien. "n Meethulpstelsel kan hierdie \\
probleem help verlig.
\end{tabular}

Taakdetinisie 'n Voertuigbestuurder besluit on in 'n spesifieke rigting agteruit te ry - sonder om in 'n botsing betrokke te raak.

Waarneming Sensors (bv. 'n videokamera en ultrasoniese sensors) op die voertuig word outomaties geaktiveer sodra na trurat borgeskakel word; en dit stuur seine (bv. videobeelde en ondioseine), wat deur die bestuurder geinterpreteer kan word.

Vergelyking Die bestuurder interpreteer die seine om, saam met normale waarnemings, seker te maak dat daar nie obstruksies agter dic voertuig is nie

Besluitneming Indien daar 'n obstruksie agter die voertuig is, kan die bestuurder betyds 'n besluit neem om stil te hou, of van koers te verander.

Taakuitvoering Die bestuurder beheer die vocrtuig o.a. op grond van die oorspronklike ritdoelwit. cie waarnemings en insette ontvang vanat die meethulpstelsel.

Tabel 3 Voorbeeld van 'n meet- en berekeningshulpstelsel

\begin{tabular}{ll}
\hline Voorbeeld & Satellietvolging van geskalakte voertuie \\
\hline Opmerkings & Hierdie is 'n parasitiese effek in die ekonomie, omdat dit \\
& hulpbronne gebruik vir iets wat in 'n ordelike samelewing \\
& onnodig is. Gelukkig kan tegnologie help om die effekte \\
& van so 'n abnormaliteit te versag (al is dit teen hoe koste).
\end{tabular}

Taakdefinisie Die volgerstelsel-operateur bepaal dat 'n spesifieke voertuig se bewegings gevolg moet word, op grond van "n noodsein vanaf' 'n geskaakte voertuigbestuurder.

Warneming Seine word via satellietverbinding gestuur vanaf'n Iransponder annboord die voertuig na 'n beheerkaner.

Vergelyking Rekenaarverwerking van die ontvangde seine en bepaling van die vocrtuig se posisic t.o.v. 'n verwysingspunt.

Besluitneming Die volgerstelsel-operateur interpreteer die gemete inligting en gee dil deur aan lede van die beskermingsdienste.

Taakuitvoering Beskermingsdienste volg en herwin die voertuig op grond van inselte vanaf die meet- en berekeningshulpstelsel.

Tabel 4 Voorbeeld van 'n beheerhulpstelsel

Voorbeeld Ekspertstelsel as ondersteuning vir 'n kasmaker

Opmerkings Om kass te maak, hang baic af van die betrokke persoon se ervaring en voorkeure. "I Rekenaargebaseerde ekspertstelsel kan gebruik word om dic operateur te lei in die stappe wat gevolg moet word.

Taakdefinisie 'n Operateur kies die tipe kaas wat gemaak moet word; en hierdie keuse bepaal o.a. die vereiste temperatuur-teentydsverloop vir die melk.

Waarneming Meting van pll, temperatuur, tydsverloop, ens.

Vergelyking Vergelyk gemete wardes met verlangde waardes en bepaal foutseine. 
Tabel 4 Voorbeeld van 'n beheerhulpstelsel (vervolg)

Beslnitneming Op grond van die foutseine en inligting in dic ekspertstelsel se databasis, besluit die rekenaar op verdere aksies wat geneem behoort te word en gee terugvoering aan dic operateur.

Thaktuitvoering Die operateur kan die ekspertstelsels se voorgestelde besluite uitvoer, mar het dic opsie om persoonlike voorkeure te inkorporeer. Die operateur word onthef van sleurwerk — soos on deurentyd $n$ horlosic baie goed dop te hou en om al die prosesveranderlikes akkuratat te meet.

Tabel 5 Voorbeeld van 'n outomatiese beheerstelsel

\begin{tabular}{|c|c|}
\hline Voorbceld & Outomatiese spoedbeheer vir 'n voertuig \\
\hline Opmerkings & $\begin{array}{l}\text { Sekere lake van die voertuigbestuurder word deur 'n } \\
\text { masjien oorgeneem en outonoom uitgevoer. }\end{array}$ \\
\hline Taakdetinisic & $\begin{array}{l}\text { Verlangde spoed word deur die voertuigbestuurder } \\
\text { ingestel. }\end{array}$ \\
\hline Waarneming & $\begin{array}{l}\text { Meting van die voertuig se werklike spoed, m.b.v. } \\
\text { meetsensors. }\end{array}$ \\
\hline lergelyking & $\begin{array}{l}\text { Bepaling van afwykings tussen die verlangde spoed en } \\
\text { die werklike spoed. }\end{array}$ \\
\hline Beslnitmeming & $\begin{array}{l}\text { Bepaling vall die beste manier om die werklike spoed } \\
\text { met dic verlangde spoed te laat ooreenstem - bv. } \\
\text { sonder om te lank te neem, maar ook sonder om } \\
\text { spoedossillasies (verbyskiet) te veroorsaak. }\end{array}$ \\
\hline Taukuitvoering & $\begin{array}{l}\text { Outomatiese regulering van brandstoftoevoer na die } \\
\text { voertuigenjin, sodanig dat die werklike spoed } \\
\text { ooreenstem met die verlangde spoed. }\end{array}$ \\
\hline
\end{tabular}

Tabel 6 Voorbeeld van 'n volledig outomatiese stelsel

\begin{tabular}{ll}
\hline Voorbeeld & Melkoutomate om kocie te melk \\
\hline Opmerkings & Melkoutomate' is tans vinnig besig om 'n werklikheid te \\
& word - veral in Europa. Ideaal behels dit 'n volledig outo- \\
nome proses, met geen inmenging van 'n operateur nic.
\end{tabular}

Tuakdefinisic Outomatiese vasstelling van die koci se speenposisies sodra sy gereed staan om gemelk te word (bv. met masjienvisie); en gebruik daarvan as stuurwaardes vir 'in robotarm wat speenhulse na die spene moet neem.

Wourneming lleting van die posisie van die robothand met dic melkmasjien se speenhuls daarin.

Vergelyking Bepaling van afwykings tussen speen- en robothand posisic (tipies i.t.v. driedimensionele ruimtelike koördinate).

Beshritneming Bepaling van die beste pad waarlangs die speenhulse na die spene toe beweeg moet word deur die robotarm en -hand.

Taakuirvoering Beheer van dic robot ten einde die speenhulse op die spene te plaas - selfs indien die koei effens sou beweeg.

Die melkoutomate wat in tabel 6 bespreek word, kan 'n melkboer en sy werkers verlig van die nodigheid om sewe dae per week, op ongemaklike tye, koeie te melk. In die agtergrond het die ontwikkeling van sulke outomate egter geverg dat ontwikkelingsingenieurs en -tegnici baie hard daaraan moes werk. Alhoewel tabel 6 aantoon dat die taakdefinisie deur die melkoutomaat self gedoen word, is dit net deels die waarheid. Die oorhoofse taakdefinisie is vooraf deur ' $n$ mens gedoen en in 'n rekenaar geprogrammeer wat dit dan herhaaldelik uitvoer. As 'n melkoutomaat eers in bedryf is, sal onderhoudstegnici sewe dae per week beskikbaar moet wees en soms op ongemaklike tye moet gaan werk. Die voordeel is dat die onderhoudspan slegs 'op bystand' hoef te wees, met 'n goeie kans dat 'n nag- of naweekwerkery nie nodig sal wees nie. Sonder die outomate was nag- en naweekwerkery vir die boer en sy werkers die reël.

\subsection{Skynoutomatisasic}

Benewens die baie voorbeelde van outomatisasie wat algemeen aangetref word, word skynoutomatisasie ook aangetref byvoorbeeld die sogenaamde outomatiese swembadskoonmaker en outomatiese hekke en motorhuisdeure. Hierdie apparate het min of geen vermoë tot waarneming, vergelyking, besluitneming of korrektiewe aksies nie, maar is suiwer meganismes om spierkrag en miskien 'n klein bietjie breinkrag, te vervang. Daar is geen sprake dat 'n huidige generasie swembadskoonmaker kan waarneem dat 'n sekere gedeelte reeds skoongemaak is, of dat dit nou al baie lank in die hoekie sit en niks doen nie. Vir so 'n swembadskoonmaker is daar nie eens 'n behoorlike taakdefinisie, waarteen die stelsel sy eie werking kan meet nie. Die skoonmaker word gewoon begrens deur fisiese beperkings, waarbinne dit lukraak rondbeweeg. By 'outomatiese' hekke en deure is daar darem meesal 'n vooraf-gedefinieerde taak - alhoewel baie eenvoudig - naamlik 'beweeg totdat die hek/deur volledig oop/ toe is'. Sulke apparate word dikwels as 'n outomatisasie wonderwerk - met intelligensie - bemark, terwyl dit in werklikheid meganisasie is, wat slegs geskik is vir eenvoudige take. Wanvoorstellings van hierdie aard kan valse verwagtinge skep - wat soms tragiese gevolge kan hê.

\section{POTENSIËLE VOORDELE VAN OUTOMATISASIE}

\subsection{Aanvulling van arbeid en verbetering van werksomstan-} dighede

Weens die moontlikhede wat gevorderde sensortegnologie bied om 'n groot hoeveelheid menslike waarnemingsvermoëns na te boots, kan dit ' $n$ belangrike rol speel in outomatiese stelsels vir die aanvulling van arbeid. Hierdie aspek is veral belangrik by take waar omgewingstoestande onaangenaam is vir operateurs, of waar kontinue proseswaarnemings noodsaaklik is. ( $D$ it is baie belangrik om daarop te let dat arbeidsaanvulling en nie blindelingse arbeidsvervanging nie, hier ter sprake is. Daar is steeds take wat nie so akkuraat deur robotte gedoen kan word as deur mense nie, en dit sal dom wees om robotte op sulke take af te dwing. ${ }^{7}$ )

Benewens die aanvulling van arbeidsvermoëns, kan outomatisasie ook bydra tot die verbetering van werks- en lewensomstandighede van werkers. Dit vind plaas op maniere soos die volgende:

- Werkers kan verlig word van stremmende take (bv. wanneer groot hoeveelhede produkte geïnspekteer, gesorteer en verpak moet word).

- Verligting van deurlopend vermoeiende take (bv. om produksieprosesse kontinu aan die gang te hou).

- Verligting van gevaarlike take (bv. interaksie met gevaarlike prosesse, masjiene en diere).

\subsection{Verhoogde produktiwiteit}

Produktiwiteit word gedefinieer as die verhouding van opbrengs tot insetkoste - wat nie verwar moet word met verhoogde produksievlakke nie. Die klem val nie op vergrote produksie nie (wat in gevalle van oorproduksie vermy moet word), maar op meer koste-effektiewe produksie. ${ }^{8}$ Produktiwiteit word dikwels slegs met die vermoëns, houdings en kennis van werkers geassosieer. Alhoewel werkers 'n sentrale rol hierin speel, moet al die produksiefaktore (natuurlike hulpbronne, arbeid, kapitaal, ondernemerskap en tegnologie) reg ingespan word ten einde 
produktiwiteit te optimeer. ${ }^{9}$ Cronje et al. ${ }^{10}$ sê:

Tegnologiese ontwikkeling, en die suksesvolle implementering daarvan, is een van die belangrikste faktore wat 'n hydrae tot produktiwiteitsverhoging kan lewer. SuidAfrikaanse ondernemings maak egter nog nie genoegsaam gebruik van die voordeel wat verbeterde tegnologie kan bied nie - in baie gevalle is Suid-1frikaunse ondernemings nog besig om teen die kompleksiteite van nuwe tegnologie te stry. Daar bestaan in Suid-Afrika 'n groot gaping tussen die beskikbare tegnologie en die gebruik daarvan in die handel en fabriekswese. Daar is derhalwe 'n dwingende behoefie aan die keuse van toepaslike tegnologiee en die gepaste implementering daarvan. wat bes/iste produktiwiteitsvoordele sal meebring

As Suid-A frikaners ernstig is oor verhoging van produktiwiteit, sal daar meer gebalanseerd na tegnologiese hulpmiddels, soos outomatisasie, gekyk moet word; en sal daar op 'n doelgerigte manier gewerk moet word om die land se tegnologiese vermoëns uit te bou en tot almal se voordeel aan te wend. Ongelukkig word ondernemers se soeke na verhoogde produktiwiteit dikwels geëtiketteer as deel van die boosheid van kapitalisme. Die waarheid is egter dat die strewe na verhoogde produktiwiteit op die duur tot almal se voordeel is - soos reeds in die agtiende eeu deur die ekonoom Adan Smith" beredeneer is.

'n Voorbeeld van outomatiseringsgedrewe produktiwiteitsverhoging word beskryf in 'n artikel wat handel oor 'n fabriek waar produktiwiteit binne drie maande met $30 \%$ verhoog is deur gebruikmaking van 'n meethulpstelsel. ${ }^{12}$ Geen werkers is vervang nie, maar outomatisasie is baie effektief gebruik om die werkers se vermoëns aan te vul.

\subsection{Verbeterde produkkwaliteit}

Prosesherhaalbaarheid, uitskakeling van menslike oordeelsfoute en kontinue produkverwerking is maar enkele faktore wat produkkwaliteit kan verhoog. Een van die norme wat dikwels deur verbruikers gebruik word om produkkwaliteit te bepaal (en om dus die prys wat produsente kan behaal, vas te stel), is produkeenvormigheid. Dit is veral die gevolg van herhaalbaarheid tydens vervaardiging, of tydens sortering en verpakking van bv. gebottelde produkte, snyblomme, vrugte en groente. In al hierdie gevalle lei eenvormigheid tot verbeterde produkkwaliteit in die oë van die verbruiker en dus tot hoër winsgewendheid vir die produsent. Vir 'n menslike operateur is dit baie moeilik (selfs onmoontlik) om konsekwentheid in produkhantering te handhaaf, terwyl dit vir 'n outomatiese masjien die natuurlike ding is om te doen.

\subsection{Effektiewer aanwending van hulpbronne}

In fabrieke met 'n 40-uurwerksweek word toerusting vir minder as $25 \%$ van die tyd gebruik en gaan baie tyd verlore wanneer prosesse aan- en afgeskakel word. Ten einde hierdie probleme te oorkom, is die een alternatief om meer as een skof per dag te werk - wat nie $n$ aangename oplossing vir alle werkers is nie. Die ander alternatief is outomatisasie, wat meebring dat prosesse deurlopend voortgaan sonder dat operateurs deurentyd nodig is.

\section{REDES VIR UITEENLOPENDE BESKOUINGS OOR OUTOMATISASIE}

\subsection{Verwagtinge wat nie vervul word nie}

Wanneer 'in persepsie by gebruikers geskep word (hetsy deur verkeerde bemarking of deur swak produkdokumentasie) dat outomatiese meganismes menslike intelligensie het en dat dit wondere vir die mens kan verrig, ontstaan die persepsie ook dikwels dat sulke meganismes heeltemaal veilig móét wees. Dit kan dan aanleiding gee tot bewustelike of onbewustelike nalatige gebruik van die meganismes - wat tragiese gevolge kan hê. So kan vele sogenaande outomatiese hekke en deure (veral van die ouer generasie apparate) byvoorbeeld nie waarneem as daar ' $n$ obstruksie in die pad daarvan is nie; en mense is daarom al deur sulke deure doodgedruk. Dit is die plig van elke tegniese ontwerper om moontlike gevare van tegnologiese hulpmiddels in wisselwerking met gebruikers baie goed te deurdink voordat dit geïmplementeer word. Sodoende sal meer realistiese verwagtinge by gebruikers bestaan en sal tegnologiese hulpmiddels nie verkeerdelik eers as wonderwerke vereer word en dan as euwels uitgekryt word nie.

\subsection{Konflikte in die arbeidsmark}

Enersyds wil baie werkers in arbeidsintensiewe bedrywe graag minder hard werk ('n natuurlike menslike behoefte); maar andersyds wil dieselfde werkers graag 'n groot salaris kry. Sulke werkers ervaar outomatisasie enersyds as 'n manier om werksladings te verlig, maar andersyds word dit dikwels deur dieselfde werkers gesien as iets wat hulle van werkgeleenthede gaan ontneem. In 'n ideale vryemarkekonomie word salarisse deur vraag en aanbod bepaal, maar aangesien daar baie versteurings van die vryemarkbeginsels in die ekonomie voorkom, is owerheidsinmenging soms noodsaaklik. Sulke inmenging laat egter sommige werknemers en sommige werkgewers voel dat hulle nie regverdig behandel word nie, en dit gee dikwels aanleiding tot arbeidsdispute (wat soms boonop nog vir politieke redes aangeblaas word). Sommige werkgewers sien outomatisasie dan as ' $n$ wonderkuur om arbeidsprobleme te oorkom. Dieselfde werkgewers kan dit egter baie maklik later as 'n euwel beskou, wat ten duurste onderhou en gereeld opgegradeer moet word indien 'n behoorlike koste-analise nie vir die totale lewensiklus gedoen is nie.

Aan die begin van die 1980's is daar beraam dat ongeveer 20000 Amerikaners in daardie dekade hul werk sou verloor as gevolg van robotika, maar terselfdertyd is beraan dat die Amerikaanse robot-industrie meer as 70000 nuwe werkgeleenthede sou skep. ${ }^{13}$ Die verlore werkgeleenthede was hoofsaaklik vir die minder geskoolde werkers, terwyl die nuwe geleenthede hoër vlakke van opleiding geverg het. Dit impliseer dat werkers in ' $n$ tyd leef waar voortdurende opleiding, ten einde hulself beter te bekwaam, noodsaaklik geword het. Ten einde stabiliteit in die ekonomie te verseker, moet werkers enersyds besef dat outomatisasie besig is om te knaag aan bestaande werkgeleenthede; en andersyds dat dit nuwe - meer uitdagende - werkgeleenthede skep. In 'n vryemarkekonomie is dit elke werker se eie verantwoordelikheid om te sorg dat hy/sy nie oorbodig raak nie; en dat daar nie vir ewig vasgehaak kan word by die ou manier van dinge doen nie. Werksekerheid hang af van werkers se persoonlike groei. As werkers nie persoonlik ontwikkel nie, ontstaan die gevaar beslis dat hulle deur masjiene vervang sal word. Werkers wat probleemoplossers is en nie maar soos geprogrammeerde zombies werk nie, sal in die toekoms in aanvraag wees en sal nie so maklik deur outomatisasie vervang kan word nie.

Beter opgeleide werknemers is 'n voorvereiste vir ekonomiese groei op die lang termyn - en dit is iets wat Suid-Afrika baie nodig het. Werkgewers moet egter ook verantwoordelik optree deur nie blindelings outomatisasie te implementeer ten einde bestuursprobleme tussen werkgewers en werknemers te probeer verdoesel nie. Enige outomatisasie behoort slegs geïmplementeer 
te word na volle oorweging van die tegniese, ekonomiese en sosiale implikasies daarvan.

Werknemers behoort die geleentheid te kry om hulself betyds te bekwaam vir werk hoër op in die arbeidshiërargie; en werkgewers behoort die geleentheid te kry om 'n behoorlike ondernemersloon te verdien deur outomatisasie te gebruik as dit voordelig kan wees. Alleen as werknemers (en hul vakbonde) en werkgewers gebalanseerd na outomatisasie kyk, sal 'n gesonde balans bereik kan word tussen die uiterstes op die spektrum tussen wonderwerk en euwel.

\subsection{Persoonlike vooroordele}

Daar is heelwat voorbeelde in die literatuur waar die voor- en nadele van die outomatisasie van spesifieke prosesse bespreek word. Die fokus op voordele of op nadele hang dikwels af van die verskillende outeurs se persoonlike vooroordele. Twee voorbeelde hiervan is Nordwall ${ }^{14}$ wat fokus op potensiële nadele van outomatisasie in lugverkeerbeheer; en Hughes \& Shott ${ }^{15}$ wat fokus op voordele van outomatisasie van die produksie van geïntegreerde stroombane. Persoonlike voorkeure speel dikwels 'n oorheersende rol in individue se plasing van outomatisasie in die spektrum tussen wonderwerk en euwel; en dit moet altyd in gedagte gehou word wanneer iemand se sieninge in hierdie verband geëvalueer word.

\section{SLOTOPMERKINGS}

Die huidige hoë tempo van tegnologiese ontwikkeling stel hoë eise aan elkeen in die arbeidsmark om by te bly met hierdie ontwikkelings. Outomatisasie is deel van hierdie snelle ontwikkelings, en dit is 'n realiteit wat nie weggewens kan word nie. Outomatisasie is nie 'n wonderwerk nie, en ook nie 'n euwel nie. Dit skakel nie die nodigheid om te werk uit nie, maar verg werk op 'n hoër vlak wat groter resultate kan lewer. Ten einde 'n meer gebalanseerde standpunt tussen hierdie twee uiterstes te kry, moet die konsepte grondliggend tot outomatisasie eers baie goed verstaan word. Alhoewel outomatisasie uit 'n tegniese en ekonomiese oogpunt heelwat potensiële voordele kan inhou, het dit ook sosiale implikasies, en is daar ook gronde vir heelwat verskillende sienings oor die meriete daarvan. Alleen deur die beperkings en die vermoëns van outomatisasie te begryp, kan die voordele daarvan optimaal benut word, en kan die nadele daarvan optimaal afgeweer word.

\section{SUMMARY}

The concept automation has different meanings for different people, and even specialists sometimes differ about its interpretation. Some consider it to be a miracle, which can perform difficult tasks, or which can overcome labour or management problems. Others see it as something reducing job opportunities, or which has to be maintained at high cost once implemented. Since automation is increasingly a part of our society, it is important to understand the concept. This paper is aimed at establishing a more balanced view of automation. The emphasis is on the definition of an automation hierarchy, on some potential advantages of automation, and on some of the most important reasons for different views on the subject.

Dictionaries define automation as something working by itself, without human intervention. This definition is vague, and the term is often misused - not only in marketing brochures, but also by technically trained people. A general mistake is to use mechanisation and automation synonymously. Mechanisation is the augmentation (or replacement) of muscle power with machines, while automation is the augmentation (or replacement) of muscle power, brain power, and sensory abilities by means of machines (mainly adaptable computer-based machines). With automation, some tasks can be executed autonomously by a machine - while this is not possible with mechanised systems. Autonomous sensing and decision-making by a machine are the cornerstones of automation; while with mechanisation, both these tasks are performed by an operator.

It is often wrongly thought that tasks which are difficult to define and to execute, should merely be automated to solve the difficulties. However, the objectives and the basic principles of any process must first be well understood before the process can be automated. Unless this is done, the operator's responsibilities cannot be transferred to a machine. Automation does not replace human responsibilities in the workplace - it merely reschedules, regroups, and redefines human functions.

Based on which tasks can be performed autonomously by a machine, an automation hierarchy can be defined as follows:

- Measurement augmentation, where automated measuring equipment is used to assist an operator controlling a process, with the sensory tasks.

- Measurement and computational augmentation, where automated measuring and processing of measurements are used to assist an operator.

- Control augmentation, using automated measuring, processing and decision-making.

- Automatic control, using automated measuring, processing, decision-making and task execution.

- Full automation, using automated task definition, measuring. processing, decision-making and task execution.

Besides the many examples of automation which are commonly encountered, pseudo-automation also occurs. This term refers to apparatus without sensing, decision-making, and corrective action abilities - e.g. so-called automatic pool cleaners, or automatic gates and doors. These devices mainly augment muscle power, without any of the traits of automation; and they are often wrongly advertised as 'automated miracles'.

Automation can potentially hold many advantages, such as: augmentation of labour and improvement of working conditions: increased productivity; improved product quality; and more efficient utilisation of resources. Only in well-designed automation, can these potential advantages be fully used.

Some of the most important reasons for different opinions about automation include: unfulfilled expectations; conflicts in the labour market; and personal biases. These factors should be taken into account when automation is considered.

The current high rate of technological developments challenges everybody in the labour market to keep up with these developments. Automation is part of these fast-track developments, and it is a reality which cannot be ignored. Automation is no miracle, but neither is it some form of evil. It does not remove the necessity for mankind to work, but it merely requires work on a higher level, since the simpler tasks can now be done by machines. Although automation can have many advantages - both technically and economically, it also has social implications; and there is justification for different views on the subject. In order to find a balanced position between the two extremes of miracle and evil, it is essential to fully understand automation and all its implications as addressed in this paper. Only by understanding the abilities and the limitations of automation, can its advantages be fully utilised, and can its disadvantages be fully prevented. 


\section{LITERATUURVERWYSINGS}

1. Amlaner. ( I. MacDonald, D.W. (1980). A Handbook on Biotelemetry and Radio Tracking (Pergamon Press, Oxford)

2. Engelberger, 1.1. (1980). Robotics in Practice - Management and Applications of Industrial Robots (Kogan Page, London).

3. Couws, J. (1998). Outomatisasie: Wonderwerk of Euwel ? (Professorale Intrecrede, Randse Afrikaanse Universiteit; ISBN 0-86970-434-6; 12 Augustus 1998)

4. Singelmann, J. (1978). From Agriculture to Services, The Transformation of Indus/ral Employment (Sage Publications, Beverly HIIlls).

5. Badenhorst, B.P. (1995). The Process Control of a Cheese Maker using Fuzzy logic (B.Ing. (Electrical \& Electronic)-thesis, Rand Afrikaans ( Iniversity)

6. Couws. 1. (1994). Tegnologic vir ten volle geoutomatiseerde melking van kocic, S.A. Tydskrif vir Natmurwetenskap en Tegnologie, 13(4), 120-124.

7. IBrittan. D. (1996). When bad things happen to good factories, Technology Review, 90, 14-15.

8. Speclmau. 1. (1989), Van Zaaier to Robot, Beelden van Landbouwtechniek (Prolessorale Intreerede, Landbouwuniversiteit Wageningen, Nederland).
9. Falkena, II.B. (1979). Die Makro-ekonomiese Verband Iussen die Openbare en Privaatsektor in Suid Afrika (Ioktorale Proefskrit in Ekonomie, Rijksuniversiteit te Groningen, Nederland).

10. Cronje, G.J. De J., Hugo, W.M.J., Neuland, E.W , Van Reenen, M.J. (reds.) (1993). Inleiding lot die Bestunrswese, derde uitgawe (Southern Boekuitgewers, Midrand).

11. Smith, A. (1776). An Inquiry into the Nature and Causes of the Wealth of Nations (Reprint - Penguin, London, 1970)

12. Anoniem (1998). Technology AND job preservation - a success story, $S A$ Instrumentation and Control, 14(3), 46.

13. K'rutz, G.W., Mailander, M.P. (1983). Automatic Combine, Robotics and Intelligent Machines in Agriculture Proc. First International ('onference on Robotics and Intelligent Machines in Agriculture (ASAE, Michigan), 128-137.

14. Nordwal, B.D. (1996). Automation: Ilelp or Hindrance? Aviation Week d Space Technology, 145, 4 November 1996, 85.

15. Hughes, R.A., Shott, J.D. (1986). The future of automation for highvolume wafer fabrication and ASIC manutacturing, Proc. IEEE, 74(12), $1775-1793$. 